\title{
DAMPAK KETERBUKAAN PERDAGANGAN DAN KINERJA MANUFAKTUR DI INDONESIA
}

\author{
Wahyu Dyah Novitasari ${ }^{1}$, Sri Hartoyo ${ }^{2}$, Lukytawati Anggraeni ${ }^{2}$ \\ ${ }^{1}$ Mahasiswa Magister Program Studi Ilmu Ekonomi, FEM IPB \\ ${ }^{2}$ Staf Pengajar FEM IPB
}

Artikel diterima Mei 2015

Artikel disetujui untuk dipublikasikan Desember 2015

\begin{abstract}
This study aims to analyze the impact of trade openness on the performance of manufacturing in Indonesia. In the study, performance and manufacturing growth indicated by the index of competitiveness and manufacturing added value. In aggregate, over the last few years, trade performance of Indonesia's manufacturing sector has decreased due to the low index of competitiveness and comparative advantage. The empirical results using an Autoregressive Distributed Lag (ARDL) model with Error Correction Approach (ECM) shows that trade openness consistently negative effect on manufacturing value added, implicitly increase one percent change in trade openness would be deficit of changes in manufacturing value added of 4.26 billion rupiah, ceteris paribus. Furthermore, the amount of labor consistently positive effect on manufacturing value added, while fixed capital variable and value-added of previous lag (a year earlier) take effect by unstable in the long term as well as short then the crisis has also negatively affect the manufacturing value added.
\end{abstract}

Keywords: Trade openness, Manufacturing Value Added, Autoregressive Distributed Lag

\section{PENDAHULUAN}

Perkembangan era globalisasi saat ini menuntut adanya keterbukaan ekonomi yang semakin luas dari setiap negara di dunia. Keterbukaan ekonomi menggambarkan semakin hilangnya hambatan dalam melakukan perdagangan, baik berupa tarif maupun non-tarif, dan semakin lancarnya mobilitas modal antarnegara. Secara teori keterbukaan ekonomi menjanjikan tantangan dan peluang yaitu dengan semakin terbukanya perdagangan antar satu negara dengan negara lainnya dapat memberikan peluang meningkatnya akses pasar produk dalam negeri di pasar internasional sekaligus juga tantangan terhadap daya saing industri dalam negeri terhadap produk luar negeri. Namun demikian manfaat yang diterima oleh setiap negara dari keterbukaan ekonomi tidak menunjukkan pola dan besaran yang sama. Bagi sebagian negara berkembang, keterbukaan berdampak negatif terhadap pertumbuhan ekonomi akan tetapi akan berdampak postif bagi negara maju yang telah mengoptimalkan keterbukaannya pada perdagangan.

Secara teoritis, perdagangan bebas dapat memberikan keuntungan secara ekonomi karena meningkatnya akses pasar dan surplus ekonomi secara keseluruhan. Perdagangan bebas dapat memberikan sejumlah manfaat, seperti terpenuhinya (1) bahan baku, penolong, dan barang modal. (2) peningkatan investasi yang akan mempengaruhi struktur industri (3) mendorong adanya peningkatan kapasitas (capacity building) untuk meningkatan daya saing industri domestik, dan meningkatan daya beli masyarakat. Namun, perdagangan bebas tidak akan dapat memberikan manfaat yang besar jika daya saing industri dalam negeri jauh lebih rendah dibandingkan dengan industri luar negeri.

Sektor industri manufaktur merupakan komponen utama penggerak dalam pembangunan perekonomian nasional dan menyumbang hampir 30 persen dalam 
pembentukan Produk Domestik Bruto (PDB) Indonesia selama sepuluh tahun terakhir. Selain besarnya pangsa industri manufaktur terhadap PDB, penyerapan tenaga kerja pada industri manufaktur juga menempati urutan atas sehingga kinerja sektor industri manufaktur mempunyai dampak nyata baik terhadap ekspor, penyerapan tenaga kerja maupun ekonomi secara keseluruhan. Kontribusi sektor industri manufaktur mengalami fluktuasi yang cukup signifikan, pada tahun 2000 kontribusinya meningkat mencapai lebih dari 27 persen sedangkan periode tahun 2006 mulai terjadi penurunan kontribusi secara fluktuatif, dalam tiga tahun terakhir sejak tahun 2010 hingga 2013 mengalami penurunan menjadi sekitar 26 persen.

Beberapa faktor yang menentukan pertumbuhan sektor manufaktur, salah satunya adalah perdagangan internasional. Ekspor sektor manufaktur akan mendorong terjadinya persaingan dan spesialisasi dalam hal produksi; skala ekonomi; alokasi sumber daya yang lebih baik dan peningkatan nilai tambah sektor ini. Sementara itu, impor memiliki dua peran, yang pertama dari sisi konsumsi, impor dapat mendorong kompetisi antara barang dari luar negeri dan barang dalam negeri. Yang kedua, impor akan mendorong percepatan alih teknologi yang dapat meningkatkan nilai tambah sektor manufaktur, khususnya jika yang diimpor adalah mesin dan barang modal. Oleh karena itu, pertumbuhan sektor manufaktur suatu negara tergantung pada sifat dari barang yang diimpor.

Seiring dengan perkembangan ekspor dunia yang meningkat, ekspor Indonesia mengalami fluktuasi dimana ada peningkatan yang cukup pesat dan penurunan yang cukup signifikan. Pada periode 1997 hingga 1999, peningkatan pangsa ekspor manufaktur cukup tinggi hingga lebih dari 50 persen dari total ekspor Indonesia dimana saat itu terjadi Asia Financial Crisis. Krisis yang melanda Asia saat itu membuat nilai tukar rupiah terdepresiasi dan dimanfaatkan untuk meningkatkan ekspor Indonesia. Seiring dengan pemulihan kondisi perekonomian Asia, kinerja ekspor manufaktur Indonesia menurun secara perlahan pada periode selanjutnya. Hal yang berkebalikan terjadi pada kinerja impor, dimana lebih dari 60 persen impor manufaktur mendominasi total impor Indonesia.

Selama periode 2010-2014, nilai ekspor manufaktur memiliki kinerja trend positif sebesar 4.26 persen sedangkan share ekspor manufaktur terhadap total ekspor tahun 2014 mencapai 41.32 persen. Pada kinerja impor, menunjukan trend positif sebesar 4.47 persen dan share impor manufaktur terhadap total impor ditahun 2014 sebesar 59.58 persen. Sedangkan selama periode tersebut neraca manufaktur terus mengalami defisit dengan rata-rata sebesar 39.39 miliar US\$ (BPS, 2015).

Berbagai literatur tentang hubungan antara keterbukaan perdagangan, output dan pertumbuhan manufaktur serta pertumbuhan ekonomi memberikan hasil yang berbeda. Beberapa penelitian yang menyatakan bahwa terdapat hubungan positif antara keterbukaan perdagangan terhadap output dan pertumbuhan manufaktur diantaranya Jonsson dan Subramanian (2001), Yanikkaya (2003), Chansomphou dan Ichihashi (2011) sedangkan yang menyimpulkan hubungan negatif diantaranya Rodriguez dan Rodrik (2001), Tabi (2011), Hye dan Lau (2012). Perbedaan hasil yang ada menunjukan bahwa tiap negara tidak serta merta mengalami peningkatan produktivitas hanya dengan berperan aktif dalam perdagangan akan tetapi karena memiliki kondisi yang berbeda baik secara perekonomian maupun kualitas sumber dayanya. Beberapa negara yang memiliki pondasi ekonomi yang kuat dan stabil secara ekonomi (negara maju) memperoleh manfaat yang sangat besar terhadap keterbukaan perdagangan yang ditandai dengan peningkatan pertumbuhan ekonomi maupun sektor industri. Hal ini berkebalikan dengan beberapa penelitian yang menyebutkan bahwa sebagian negara berkembang mendapatkan efek negatif dari keterbukaan karena kurang mampu mengoptimalkan keterbukaan tersebut. Perbedaan itu menunjukan bahwa didalam perdagangan tidak hanya terdapat aliran barang dan jasa dari pasar internasional, namun juga membuka kemungkinan terjadinya transfer teknologi.

Berdasarkan latar belakang dan perumusan masalah yang sudah dijelaskan, 
Peneliti melakukan pengujian empiris terhadap kasus di Indonesia dengan menggunakan sektor manufaktur sebagai tinjauan utamanya. Hipotesis yang disampaikan adalah keterbukaan perdagangan berpengaruh secara positif terhadap nilai tambah manufaktur. Selanjutnya modal tetap dan jumlah tenaga kerja juga berpengaruh positif terhadap nilai tambah manufaktur. Hasil elaborasi tersebut merujuk pada tujuan penelitian yaitu

1. Menganalisa kinerja industri manufaktur Indonesia

2. Menganalisa pengaruh keterbukaan perdagangan dan penggunaan input produksi (modal tetap dan jumlah tenaga kerja) terhadap nilai tambah manufaktur

3. Menganalisia pengaruh faktor guncangan dan random shock terhadap nilai tambah manufaktur, modal tetap dan jumlah tenaga kerja dalam model.

\section{METODE PENELITIAN}

\section{Jenis dan Sumber Data}

Data yang digunakan dalam penelitian ini merupakan data sekunder yang diperoleh dari berbagai sumber antara lain Bank Indonesia yaitu data pertumbuhan PDB, BPS yaitu data ekspor impor Indonesia dan jumlah tenaga kerja, World Development Indicators yaitu data keterbukaan perdagangan, pertumbuhan manufaktur, modal tetap dengan tahun konstan 2010 dan nilai tambah manufaktur dengan tahun konstan 2010. Penelitian ini menggunakan data time series tahunan dari 1988 hingga 2015.

\section{Metode Analisis}

Tahapan analisa dalam penelitian ini menggunakan dua pendekatan yaitu daya saing dan ekonometri. Pendekatan daya saing digunakan untuk menjawab tujuan penelitian yang pertama yaitu dengan menggunakan Indek Spesialisasi Perdagangan (ISP) dan Revealed Comparatif Advantage (RCA). Pendekatan ekonometri Autoregressive Distributed Lag (ARDL) model Error Correction (ECM) digunakan untuk menjawab tujuan penelitian kedua, kemudian yang terakhir Pendekatan ekonometri Impulse Response Function (IRF) dan analisis
Forecast Error Variance Decompotition (FEVD) untuk menjawab tujuan penelitian yang ketiga.

\section{Indeks Spesialisasi Perdagangan (ISP)}

ISP digunakan untuk menganalisis tahapan perkembangan suatu produk. Secara implisit, indeks ini mempertimbangkan sisi permintaan dan sisi penawaran, dimana ekspor identik dengan suplai domestik dan impor adalah permintaan domestik, atau sesuai dengan teori perdagangan internasional, yaitu teori net of surplus, dimana ekspor dari suatu barang terjadi apabila ada kelebihan atas barang tersebut di pasar domestik. Nilai ISP berkisar antara +1 dan -1 . Jika nilai dari ISP positif (di atas 0 sampai dengan +1 ) maka komoditi manufaktur dikatakan mempunyai daya saing kuat atau Indonesia cenderung menjadi negara pengekspor. Jika nilai ISP negatif (di bawah 0 sampai dengan -1), maka komoditi manufaktur berdaya saing rendah atau Indonesia cenderung menjadi negara pengimpor.

$$
I S P=\frac{X_{m j}-M_{m j}}{X_{m j}+M_{m j}}
$$

\section{Dimana:}

Nilai ekspor manufaktur $\mathrm{mj}$

$\mathrm{mj}$

\section{Revealed Comparatif Advantage (RCA)}

Indikator yang dapat menunjukkan tingkat daya saing suatu produk dari suatu negara dengan menganggap bahwa keunggulan kompetitif direfleksikan dalam ekspornya. Jika nilai RCA suatu negara untuk komoditas tertentu adalah lebih besar dari satu (1), maka negara bersangkutan memiliki keunggulan komparatif di atas rata-rata dunia untuk komoditas tersebut. Sebaliknya, bila lebih kecil dari satu (1), berarti keunggulan komparatif untuk komoditi tersebut dibawah rata-rata dunia. Semakin besar nilai RCA, semakin tinggi pula tingkat keunggulan komparatifnya. 


$$
\mathrm{RCA}=\frac{\mathrm{X}_{\mathrm{mj} / \mathrm{X}_{\mathrm{j}}}}{\mathrm{X}_{\mathrm{mw}} / \mathrm{X}_{\mathrm{w}}}
$$

Dimana:

$\mathrm{X}_{\mathrm{mj}}=$ Nilai ekspor manufaktur $(\mathrm{m})$ Indonesia (j) ke dunia (dalam US\$)

$\mathrm{X}_{\mathrm{j}}=$ Nilai ekspor total Indonesia ( $\mathrm{j}$ ) ke dunia (dalam US\$)

$\mathrm{X}_{\mathrm{mw}}=$ Nilai ekspor manufaktur $(\mathrm{m})$ dunia (w) (dalam US\$)

$\mathrm{X}_{\mathrm{w}}=$ Nilai ekspor total dunia (w) (dalam US\$).

\section{Metode Analisis Error Correction Model (ECM) dan Autoregressive Distributed Lag}

Model ARDL digunakan karena data penelitian merupakan data time series yang tidak stasioner dalam level, kemudian data mengandung faktor autokorelasi (berkorelasi dengan variabel itu sendiri pada beberapa lag waktu). Selain itu ARDL dapat menangkap pengaruh dari faktor guncangan dan random shock secara jangka pendek maupun panjang.

Pemilihan variabel penelitian penelitian dalam model mengacu pada penelitian Mahadevan (2002), sedangkan model persamaan regresinya mengacu pada penelitian Chandran dan Munusamy (2009). Variabel yang digunakan adalah nilai tambah manufaktur, modal tetap, tenaga kerja dan keterbukaan perdagangan. Variabel dependen dalam model adalah perubahan nilai tambah manufaktur sedangkan variabel independennya yaitu jumlah tenaga kerja, modal tetap, keterbukaan perdagangan dan dummy variabel. Model tersebut digunakan karena peneliti karena ingin mengetahui hubungan dari sisi penawaran atau dari input produksi. Pembeda variabel yang digunakan peneliti adalah penambahan variabel dummy krisis yang terjadi di Indonesia sehingga model tersebut menjadi:

$$
\begin{aligned}
& \Delta \mathrm{MVA}_{\mathrm{t}} \\
& =\alpha_{0}+\mathrm{D}+\sum_{\mathrm{i}=1}^{\mathrm{k}} \beta_{\mathrm{i}} \Delta \mathrm{MVA}_{\mathrm{t}-\mathrm{i}} \\
& +\sum_{\mathrm{i}=1}^{\mathrm{k}} \lambda_{\mathrm{i}} \Delta \mathrm{GFC}_{\mathrm{t}-\mathrm{i}}+\sum_{\mathrm{i}=1}^{\mathrm{k}} \gamma_{\mathrm{i}} \Delta \mathrm{LABOR}_{\mathrm{t}-} \\
& +\sum_{\mathrm{i}=1}^{\mathrm{k}} \xi_{\mathrm{i}} \Delta \mathrm{TO}_{\mathrm{t}-\mathrm{i}}+\theta_{1} \mathrm{MVA}_{\mathrm{t}-\mathrm{i}} \\
& +\theta_{2} \mathrm{GFC}_{\mathrm{t}-\mathrm{i}}+\theta_{3} \mathrm{LABOR}_{\mathrm{t}}+\theta_{4} \mathrm{TO}_{\mathrm{t}} \\
& +\varepsilon_{\mathrm{t}}
\end{aligned}
$$

Dimana:

$$
\begin{aligned}
& \text { D = Variabel dummy } \\
& \text { krisis (0: saat tidak } \\
& \text { krisis, 1: saat krisis) } \\
& \Delta \mathrm{MVA}_{\mathrm{t}-\mathrm{i}}=\text { Perubahan nilai } \\
& \text { tambah manufaktur } \\
& \text { pada tahun } \mathrm{t}-\mathrm{i} \text { dalam } \\
& \text { satuan rupiah (konstan } \\
& \text { tahun 2010) } \\
& \Delta \mathrm{GFC}_{\mathrm{t}-\mathrm{i}}=\text { Perubahan gross fixed } \\
& \text { capital pada tahun } \mathrm{t}-\mathrm{i} \\
& \text { dalam satuan rupiah } \\
& \text { (konstan tahun 2010) } \\
& \triangle \mathrm{LABOR}_{\mathrm{t}-\mathrm{i}}=\text { Perubahan jumlah } \\
& \text { tenaga kerja } \\
& \text { manufaktur pada } \\
& \text { tahun t-i dalam satuan } \\
& \text { jumlah orang } \\
& \Delta \mathrm{TO}_{\mathrm{t}-\mathrm{i}} \quad=\text { Perubahan } \\
& \text { keterbukaan } \\
& \text { perdagangan pada } \\
& \text { tahun t-i dalam } \\
& \text { persentase } \\
& \mathrm{MVA}_{\mathrm{t}-\mathrm{i}}=\text { Nilai tambah } \\
& \text { manufaktur pada } \\
& \text { tahun t-i satuan rupiah } \\
& \text { (konstan tahun 2010) } \\
& \mathrm{GFC}_{\mathrm{t}-\mathrm{i}}=\text { Gross fixed capital } \\
& \text { pada tahun t-i satuan } \\
& \text { rupiah (konstan tahun } \\
& 2010 \text { ) } \\
& \text { LABOR }_{\mathrm{t}}=\text { Jumlah tenaga kerja } \\
& \text { tahun ke } t \text { dalam } \\
& \text { satuan jumlah orang } \\
& \mathrm{TO}_{\mathrm{t}} \quad=\text { Keterbukaan } \\
& \text { perdagangan tahun } \\
& \text { ke-t dalam persentase }
\end{aligned}
$$




$$
\begin{array}{lll}
\alpha_{0} & \text { Konstanta / intersep } \\
\beta_{\mathrm{i}}, \lambda_{\mathrm{i}}, \gamma_{\mathrm{i}}, \xi_{\mathrm{i}}= & \text { Parameter yang } \\
& \text { diestimasi untuk } \\
& \text { jangka pendek } \\
\theta_{1}, \theta_{2}, \theta_{3}, \theta_{4}= & \text { Parameter yang } \\
& \text { diestimasi untuk } \\
& \text { jangka panjang } \\
= & \text { error term } \\
\varepsilon_{t} & \text { Lag } \\
i & =\text { Tahun }
\end{array}
$$

$\beta_{\mathrm{i}}, \lambda_{\mathrm{i}}, \gamma_{\mathrm{i}}, \xi_{\mathrm{i}}>0 ; \theta_{1}, \theta_{2}, \theta_{3}, \theta_{4}, \theta_{5}>0$ $\alpha_{0}>0$

Analisis ARDL dilakukan menggunakan program Eviews 8.0. Tahapan pengujian yang dilakukan adalah uji akar unit, uji kointegrasi, uji Granger causality, estimasi ARDL dan yang terakhir analisis Impulse Response Function (IRF), dan analisis Forecast Error Variance Decompotition (FEVD)

\section{Perkembangan kinerja perdagangan dan produktivitas industri manufaktur Indonesia}

Sektor industri manufaktur yaitu sektor yang mencakup semua perusahaan atau usaha di bidang industri yang melakukan kegiatan mengubah barang dasar menjadi barang jadi atau setengah jadi dan atau barang yang kurang nilainya menjadi barang yang lebih tinggi nilainya. Sektor ini adalah salah satu pemegang peranan penting dalam perekonomian Indonesia karena dapat menghasilkan produk yang dapat diperdagangkan dan membuka lapangan kerja. Sektor manufaktur terdiri dari sembilan sektor yaitu sektor industri makanan, minuman, dan tembakau; sektor industri tekstil, pakaian jadi, dan kulit; sektor industri kayu dan barang-barang dari kayu, termasuk perabot rumah tangga; sektor industri kertas dan barang-barang dari kertas, percetakan, dan penerbitan; sektor industri kimia dan barang-barang dari bahan kimia, minyak bumi, batu bara, karet, dan plastik; sektor industri bahan galian bukan logam, kecuali minyak bumi dan batu bara; sektor industri logam dasar; sektor industri barang dari logam, mesin, dan peralatannya dan sektor industri pengolahan lainnya. Kinerja sektor manufaktur tidak lepas dari daya saing industri dan perkembangan perdagangannya.

\section{Daya Saing}


Secara agregat kinerja daya saing sektor manufaktur dapat ditunjukan pada Tabel 1, berdasarkan nilai ISP dapat ditunjukan sektor manufaktur Indonesia kurang kompetitif secara agregat. Nilai indeks ISP antara -0.51 sampai 0 berarti berada tahap substitusi impor yang menunjukkan daya saing rendah, dikarenakan tingkat produksinya tidak cukup tinggi untuk mencapai skala ekonominya atau produksi dalam negeri masih lebih kecil daripada permintaan dalam negeri. Selama $\begin{array}{llll}\text { periode } & 1998 & -2007 & \text { Indonesia }\end{array}$ mengindikasikan tahap pertumbuhan yang berarti bahwa industri manufaktur mulai meningkatkan ekspornya sedangkan periode 2008-2015 mengindikasikan sebagai negara importir untuk produk manufaktur.

Nilai indek RCA mengacu pada daya saing manufaktur Indonesia terhadap daya saing dunia, secara agregat nilai RCA produk manufaktur Indonesia kurang dari satu, yang berarti memiliki daya saing rendah dibawah Tabel 1 Perkembangan perdagangan manufaktur Indonesia tahun 1996 -2014

\begin{tabular}{|c|c|c|c|c|c|c|c|c|}
\hline Tahun & ISP & RCA & $\begin{array}{c}\text { Nilai } \\
\text { Ekspor } \\
\text { Manufaktur } \\
\text { (Miliar } \\
\text { US\$) }\end{array}$ & $\begin{array}{l}\text { Share } \\
(\%) \\
\text { terhadap } \\
\text { Total } \\
\text { Ekspor }\end{array}$ & $\begin{array}{c}\text { Nilai } \\
\text { Impor } \\
\text { Manufaktur } \\
\text { (Miliar } \\
\text { US\$) }\end{array}$ & $\begin{array}{c}\text { Share } \\
(\%) \\
\text { terhadap } \\
\text { Total } \\
\text { Impor }\end{array}$ & $\begin{array}{c}\text { Necara } \\
\text { Manufaktur }\end{array}$ & $\begin{array}{l}\text { Keterbukaan } \\
\text { Perdagangan }\end{array}$ \\
\hline & (a) & (b) & (c) & (d) & $(\mathrm{e})$ & (f) & $(g)=(c-e)$ & (h) \\
\hline 1996 & -0.18 & 0.46 & 19.22 & 38.58 & 27.78 & 73.39 & -8.56 & 40.79 \\
\hline 1997 & -0.08 & 0.53 & 23.55 & 44.06 & 27.65 & 76.18 & -4.10 & 49.87 \\
\hline 1998 & 0.18 & 0.61 & 25.06 & 51.31 & 17.39 & 72.20 & 7.67 & 89.74 \\
\hline 1999 & 0.26 & 0.54 & 21.90 & 44.99 & 13.00 & 62.03 & 8.90 & 60.40 \\
\hline 2000 & 0.19 & 0.57 & 28.55 & 45.96 & 19.25 & 67.17 & 9.30 & 66.05 \\
\hline 2001 & 0.18 & 0.57 & 25.64 & 45.52 & 17.72 & 65.48 & 7.92 & 59.14 \\
\hline 2002 & 0.19 & 0.55 & 25.20 & 44.09 & 17.10 & 64.41 & 8.10 & 49.83 \\
\hline 2003 & 0.21 & 0.53 & 25.86 & 42.36 & 17.03 & 61.88 & 8.84 & 45.28 \\
\hline 2004 & 0.15 & 0.64 & 36.04 & 50.34 & 26.40 & 56.75 & 9.64 & 48.92 \\
\hline 2005 & 0.12 & 0.61 & 40.38 & 47.14 & 31.62 & 54.80 & 8.75 & 56.92 \\
\hline 2006 & 0.16 & 0.58 & 44.71 & 44.35 & 32.19 & 52.72 & 12.51 & 50.52 \\
\hline 2007 & 0.11 & 0.56 & 48.59 & 42.59 & 39.19 & 52.62 & 9.40 & 48.84 \\
\hline 2008 & -0.20 & 0.54 & 53.23 & 38.85 & 80.04 & 61.95 & -26.82 & 52.36 \\
\hline 2009 & -0.15 & 0.55 & 47.14 & 40.46 & 63.33 & 65.41 & -16.2 & 39.56 \\
\hline 2010 & -0.20 & 0.52 & 59.05 & 37.42 & 87.69 & 64.64 & -28.65 & 38.86 \\
\hline 2011 & -0.22 & 0.48 & 69.58 & 34.19 & 107.87 & 60.79 & -38.29 & 42.66 \\
\hline 2012 & -0.28 & 0.51 & 69.24 & 36.44 & 121.87 & 63.57 & -52.63 & 41.59 \\
\hline 2013 & -0.24 & 0.54 & 69.22 & 37.92 & 113.59 & 60.86 & -44.36 & 40.46 \\
\hline 2014 & -0.19 & 0.57 & 72.84 & 41.39 & 106.2 & 59.60 & -33.35 & 39.81 \\
\hline 2015 & -0.16 & 0.58 & 67.79 & 45.08 & 93.76 & 65.71 & -25.97 & 33.99 \\
\hline
\end{tabular}

Sumber : diolah dari data Kementerian Perdagangan, 2016

rata-rata dunia dengan kata lain produk manufaktur Indonesia belum memiliki keunggulan komparatif. Jika dikaitkan dengan nilai ISP, sebenarnya sektor manufaktur
Indonesia memiliki potensi sangat besar mengingat banyaknya sektor yang masih dapat dikembangkan terbukti dengan pernah berada pada tahap pertumbuhan (peningkatan ekspor).

\section{Keterbukaan Perdagangan}

Pengukuran keterbukaan perdagangan dengan menggunakan rasio ekspor ditambah dengan impor dibandingkan terhadap GDP. Secara konseptual ingin mengetahui intensitas kegiatan perdagangan, sementara secara definisi keterbukaan ialah menghilangkan atau mengurangi kebijakan yang menghambat terjadinya perdagangan internasional. Nilai keterbukaan perdagangan Indonesia cukup berfluktuatif dengan nilai paling tinggi adalah 89,74 persen pada tahun 1998 dimana saat itu adalah masa Asian Financial Crisis. Pada saat itu nilai mata uang rupiah sangat terdepresiasi sehingga harga ekspor manufaktur Indonesia 
Tabel 2 Sepuluh komoditas unggulan sektor manufaktur Indonesia tahun 2010-2015

\begin{tabular}{|c|c|c|c|c|c|c|c|c|}
\hline \multirow{2}{*}{ HS 2} & \multirow{2}{*}{ Uraian } & \multicolumn{2}{|c|}{$\begin{array}{l}\text { Nilai Ekspor } \\
\text { (Miliar US\$) }\end{array}$} & \multirow{2}{*}{$\begin{array}{l}\text { Trend }(\%) \\
2010-2015\end{array}$} & \multicolumn{2}{|c|}{ ISP } & \multicolumn{2}{|c|}{ RCA } \\
\hline & & 2010 & 2015 & & 2010 & 2015 & 2010 & 2015 \\
\hline 85 & $\begin{array}{l}\text { MESIN/PERALATAN } \\
\text { LISTRIK }\end{array}$ & 10,37 & 8,56 & $-3,90$ & $-0,20$ & $-0,29$ & 0,55 & 0,44 \\
\hline 87 & $\begin{array}{l}\text { KENDARAAN DAN } \\
\text { BAGIANNYA }\end{array}$ & 2,90 & 5,42 & 13,43 & $-0,33$ & 0,01 & 0,25 & 0,41 \\
\hline 84 & $\begin{array}{l}\text { MESIN-MESIN/PESAWAT } \\
\text { MEKANIK }\end{array}$ & 4,99 & 5,22 & 0,90 & $-0,60$ & $-0,62$ & 0,27 & 0,29 \\
\hline 64 & ALAS KAKI & 2,50 & 4,51 & 11,12 & 0,82 & 0,83 & 2,55 & 4,04 \\
\hline 62 & $\begin{array}{l}\text { PAKAIAN JADI BUKAN } \\
\text { RAJUTAN }\end{array}$ & 3,61 & 3,98 & 1,05 & 0,91 & 0,89 & 2,14 & 2,22 \\
\hline $\begin{array}{l}48 \\
71\end{array}$ & $\begin{array}{l}\text { KERTAS/KARTON } \\
\text { PERHIAASAN/PERMATA }\end{array}$ & $\begin{array}{l}4,19 \\
0,23\end{array}$ & $\begin{array}{l}3,57 \\
3,32\end{array}$ & $\begin{array}{r}-3,30 \\
74,04\end{array}$ & $\begin{array}{l}0,59 \\
0,60\end{array}$ & $\begin{array}{l}0,46 \\
0,98\end{array}$ & $\begin{array}{l}2,28 \\
0,06\end{array}$ & $\begin{array}{l}2,14 \\
0,69\end{array}$ \\
\hline 61 & $\begin{array}{l}\text { BARANG-BARANG } \\
\text { RAJUTAN }\end{array}$ & 2,89 & 3,31 & 1,69 & 0,92 & 0,90 & 1,61 & 1,81 \\
\hline 44 & $\begin{array}{l}\text { KAYU, BARANG DARI } \\
\text { KAYU }\end{array}$ & 2,29 & 3,00 & 5,43 & 0,84 & 0,88 & 2,05 & 2,68 \\
\hline 38 & $\begin{array}{l}\text { BERBAGAI PRODUK } \\
\text { KIMIA }\end{array}$ & 1,87 & 2,69 & 6,42 & 0,12 & 0,17 & 1,15 & 1,63 \\
\hline
\end{tabular}

Sumber : (diolah dari data Kementerian Perdagangan dan WITS, 2016)

keterbukaan perdagangan semakin menurun hingga diperiode 2014-2015 cukup rendah berkisar antara 33,89 persen, hal tersebut menunjukan bahwa intensitas perdagangan Indonesia tidak terlalu besar. Hal tersebut didukung pula dengan perlambatan ekonomi dunia yang membuat penurunan permintaan akan ekspor manufaktur dari Indonesia.

\section{Neraca dan Share Manufaktur}

Perkembangan neraca manufaktur Indonesia secara agregrat menunjukan kinerja yang kurang baik selama kurun waktu 8 tahun terakhir, akan tetapi perkembangan positif mulai terlihat dengan menurunnya nilai defisit tahun 2015 mencapai 25.97 miliar US\$. Jika dikaitkan dengan share ekspor manufaktur terhadap total ekspor, maka terjadi peningkatan share sedikit demi sedikit menjadi sekitar 38-40 persen. Hal ini menunjukan terjadi peningkatan ekspor manufaktur Indonesia ditengah lesunya pertumbuhan ekonomi dunia. Menurunnya peran sektor manufaktur dalam ekspor Indonesia sejak tahun 2001 disebabkan oleh menurunnya daya saing produk manufaktur Indonesia dibandingkan dengan negara-negara pesaingnya, yang antara lain karena apresiasi nilai rupiah dan kenaikan dalam upah riil (laporan Bank Dunia, 2014, ADB 2014).

Secara agregat sektor manufaktur menunjukan kinerja kurang kompetitif dan tidak memiliki daya saing akan tetapi jika mencermati lebih lanjut terdapat beberapa sub
Selain itu, kualitas infrastruktur, termasuk transportasi dan logistik, telah menjadi penghalang untuk pertumbuhan, tidak hanya di sektor manufaktur tetapi juga di sektor lain. Proporsi share impor manufaktur Indonesia masih cukup tinggi sekitar 60 persen dari total impor Indonesia, hal ini yang menjadi salah satu penyebab terjadinya defisit pada neraca manufaktur.

\section{Ekspor dan Impor Manufaktur}

Kinerja ekspor manufaktur Indonesia menunjukan peningkatan selama dua puluh tahun terakhir. Banyak faktor yang mempengaruhinya seperti kondisi domestik maupun internasional. Krisis ekonomi 2007/2008 dan tahun 2010 menyebabkan rupiah terdepresiasi akibatnya nilai ekspor manufaktur Indonesia meningkat akan tetapi seiring pemulihan ekonomi justru nilai ekspor Indonesia mengalami penurunan. Komposisi ekspor manufaktur Indonesia mencapai rata-rata 69.74 miliar US\$ selama 5 tahun terakhir. Secara umum impor manufaktur mengalami kenaikan yang signifikan pada periode 2008 hingga mencapai 80.10 miliar US\$ dan terus meningkat hingga periode 2014 menjadi 106.20 miliar US\$.

sektor manufaktur memiliki keunggulan. Berdasarkan kelompok HS 2, terdapat sepuluh komoditas unggulan ekspor sektor manufaktur dengan mempertimbangankan nilai ekspor, 
trend perdagangan dan daya saingnya selama 5 tahun terakhir. Berdasarkan Tabel 2, terdapat sepuluh komoditas ekspor manufaktur unggulan Indonesia yang memiliki nilai ekspor terbesar, akan tetapi hanya beberapa produk yang memiliki trend positif yang baik diantaranya: kendaraan dan bagiannya (HS 87), alas kaki (HS 64), pakaian jadi bukan rajutan (62), perhiasan/ permata (HS 71), berbagai produk kimia (HS 38), kayu, barang dari kayu (HS 44) dan barang-barang rajutan (61). Dari beberapa kelompok manufaktur yang telah disebutkan, hanya beberapa yang memiliki daya saing yang cukup tinggi, yaitu alas kaki; pakaian jadi bukan rajutan; perhiasan/permata; barang-barang rajutan kayu, barang dari kayu.

Sektor alas kaki merupakan ekspor komoditas utama Indonesia yang berkaitan langsung dengan pengembangan industri nasional. Industri ini menyerap tenaga kerja yang cukup besar disamping dalam produksinya bergantung pada bahan baku dari alam dan bahan sintesis yang cukup besar. Sektor berikutnya adalah tekstil dan produk tekstil (TPT) yang juga merupakan industri prioritas didalam kebijakan industri nasional sesuai Peraturan Presiden No. 28 tahun 2008. Sektor pakaian jadi bukan rajutan adalah produk garmen termasuk didalamnya baju pria dan wanita, jaket, pakaian dalam maupun gaun pengantin. Sedangkan barang-barang rajutan berbahan dasar benang rajut yang bahan bakunya serat buatan seperti polyester dan rayon. Kedua sektor tekstil ini mengarah pada penggunaan low technology dan membutuhkan jumlah tenaga kerja yang cukup banyak. Selanjutnya sektor kayu, barang dari kayu adalah merupakan produk kehutanan yang pastinya bersumber pada bahan baku alam. Salah satu keunggulan sektor ini adalah produk kayu lapis dan furnitur Indonesia yang cukup berdaya saing. Sektor perhiasan/ permata menjadi pendatang baru produk unggulan ekspor manufaktur saat ini, hal tersebut terlihat dari trend perdagangan selama 5 tahun terakhirnya mencapai sekitar 70 persen. Daya saing sektor perhiasan/permata cukup tinggi, dengan nilai ISP 0,98 yang menunjukkan bahwa Indonesia sebagai pengekspor produk ini, selanjutnya dari nilai RCA terjadi peningkatan nilai yang cukup tinggi menjadi 0,69 ditahun 2015.

Komposisi impor Indonesia terbagi menjadi tiga kelompok besar yaitu barang konsumsi, bahan baku penolong dan barang modal. Selama periode 2010-2014, rata-rata impor barang konsumsi sebesar 12.52 miliar US\$ dengan share rata-rata 7.21 persen, rata-rata impor bahan baku penolong sebesar 129.80 miliar US\$ dengan share rata-rata 74.54 persen kemudian rata-rata impor barang modal sebesar 31.80 miliar US\$ dengan share rata-rata 18.35 persen. Bahan baku yang digunakan oleh sektor manufaktur di Indonesia menggunakan sumber daya alam dan bahan baku penolong yang bersumber dari impor.

Berdasarkan kelompok HS 2, terdapat sepuluh komoditas impor manufaktur dengan mempertimbangankan nilai impor, trend perdagangan, pangsa dan trend impor dunia selama 5 tahun terakhir. Dari Tabel 3 tersebut dapat diketahui bahwa impor utama Indonesia merupakan bahan baku dan barang modal yang digunakan dalam industri. Trend impor cukup tinggi untuk beberapa barang seperti mesin-mesin/pesawat mekanik (HS 84), plastik dan barang dari plastik (HS 39), bahan kimia organik (HS 29), benda-benda dari besi dan baja (HS 73), perangkat optik (HS 90) dan berbagai produk kimia (HS 38). Berdasarkan pangsa impor tahun 2015, kesepuluh sektor tersebut mewakili lebih dari 50 persen total impor Indonesia, dengan pangsa impor paling tinggi adalah mesin -mesin/pesawat mekanik. Trend impor dunia yang positif menunjukkan bahwa banyak permintaan untuk produk tersebut di dunia. 
Tabel 3 Sepuluh komoditas impor manufaktur Indonesia tahun 2010-2015

\begin{tabular}{|c|c|c|c|c|c|c|c|}
\hline \multirow{2}{*}{ HS 2} & \multirow{2}{*}{ Uraian } & \multicolumn{2}{|c|}{$\begin{array}{l}\text { Nilai Impor (Miliar } \\
\text { US\$) }\end{array}$} & \multirow{2}{*}{$\begin{array}{l}\text { Trend }(\%) \\
\text { Impor } \\
\text { Indonesia } \\
2010-2015\end{array}$} & \multicolumn{2}{|c|}{ Pangsa Impor } & \multirow{2}{*}{$\begin{array}{l}\text { Trend (\%) } \\
\text { Impor Dunia } \\
\text { 2010-2015 }\end{array}$} \\
\hline & & 2010 & 2015 & & 2010 & 2015 & \\
\hline 84 & $\begin{array}{l}\text { MESIN-MESIN/PESAWAT } \\
\text { MEKANIK }\end{array}$ & 20,02 & 22,38 & 1,87 & 14,76 & 15,68 & 1,12 \\
\hline 85 & $\begin{array}{l}\text { MESIN/PERALATAN } \\
\text { LISTRIK }\end{array}$ & 15,63 & 15,52 & $-0,70$ & 11,52 & 10,88 & 2,54 \\
\hline 39 & $\begin{array}{l}\text { PLASTIK DAN BARANG } \\
\text { DARI PLASTIK }\end{array}$ & 4,82 & 6,92 & 7,12 & 3,55 & 4,85 & 1,85 \\
\hline 72 & BESI DAN BAJA & 5,74 & 6,04 & 0,45 & 4,23 & 4,24 & $-4,10$ \\
\hline 29 & BAHAN KIMIA ORGANIK & 5,33 & 5,73 & 1,69 & 3,93 & 4,01 & $-0,59$ \\
\hline 87 & $\begin{array}{l}\text { KENDARAAN DAN } \\
\text { BAGIANNYA }\end{array}$ & 5,74 & 5,34 & $-3,24$ & 4,23 & 3,74 & 3,99 \\
\hline 73 & $\begin{array}{l}\text { BENDA-BENDA DARI BESI } \\
\text { DAN BAJA }\end{array}$ & 3,45 & 3,72 & 2,58 & 2,54 & 2,60 & 1,96 \\
\hline 31 & PUPUK & 1,40 & 2,00 & 0,97 & 1,03 & 1,40 & $-0,20$ \\
\hline 90 & PERANGKAT OPTIK & 1,71 & 1,92 & 3,05 & 1,26 & 1,35 & 2,62 \\
\hline 38 & BERBAGAI PRODUK KIMIA & 1,47 & 1,89 & 5,87 & 1,08 & 1,32 & 1,60 \\
\hline
\end{tabular}

Sumber : (diolah dari data Kementerian Perdagangan dan WITS, 2016)

Keterangan :

Pangsa impor adalah share impor manufaktur terhadap total impor Indonesia

Sektor manufaktur plastik dan barang dari plastik serta bahan kimia organik memiliki trend positif yang berarti impor terhadap produk ini masih cukup tinggi seperti yng diketahui bahwa produk ini merupakan bahan baku industri yang paling banyak digunakan. Hal tersebut juga didukung dengan peningkatan kebutuhan plastik domestik yang tinggi membuat impor plastik terus menanjak. Potensi kedua sektor didorong oleh pertumbuhan sektor industri makanan dan minuman domestik yang cukup pesat.

Ditengah pesatnya perkembangan teknologi informasi dan komunikasi mendorong peningkatan impor terhadap sektor perangkat optik. Selain untuk mendukung operasional dalam industri, perangkat optik ini mampu mendukung perekonomian dari sektor jasa, industri kreatif dan pendidikan. Trend impor perangkat optik dunia mencapai angka yang positif, yang menunjukan bahwa tidak hanya Indonesia yang berusaha untuk maju dalam teknologi dan informasi. Sektor selanjutnya yang cukup tinggi trend perdagangannya adalah berbagai produk kimia. Seperti kita ketahui, bahwa sektor ini bahan baku penting dalam berbagai industri diantara industri kertas, kayu, karet, semen dan lainnya. Sektor ini pun merupakan pendukung untuk industri yang berorientasi pada ekspor. Sehingga dapat kita simpulkan bahwa impor manufaktur sangat erat kaitannya dengan ekspor sektor manufaktur di Indonesia.

\section{Produktivitas Manufaktur}

Produktivitas manufaktur Indonesia dapat diperoleh salah satunya dengan nilai tambah manufaktur. Faktor yang mempengaruhi pertumbuhan manufaktur selain tenaga kerja dan modal tetap adalah kemajuan teknologi, akan tetapi dalam penelitian ini kemajuan teknologi diasumsikan variabel eksogen. Secara aritmatika, pertumbuhan manufaktur secara mikro dihitung dari pertumbuhan yang disebabkan oleh kapital, tenaga kerja, dan perubahan nilai tambah dalam pemakaian sumber-sumber tersebut. Pertumbuhan manufaktur erat kaitannya dengan tingkat keterbukaan ekonomi dan perdagangan serta stabilitas makroekonomi. Salah satu indikator makroekonomi meliputi tingkat inflasi, nilai tukar efektif riil.

Kinerja sektor manufaktur tidak lepas dari keadaan perekonomian baik eksternal maupun internal. Sektor manufaktur yang bahan baku produksinya berasal dari barang impor sangat sensitif terhadap perubahan nilai 
tukar dan pengaruh ada tidaknya krisis yang terjadi di dunia. Seiring dengan perubahan yang terjadi pada nilai tukar maka secara tidak langsung mempengaruhi inflasi yang merupakan tolok ukur daya beli masyarakat.

Pada periode 1997-1998, krisis Asia Financial Crisis melanda Indonesia tahun 1997/1998, PDB tahun 1998 tumbuh negatif sebesar 13.3 persen yang juga diikuti oleh penurunan pertumbuhan sektor manufaktur sebesar 15.4 persen.

Penurunan yang tajam pada output manufaktur tahun 1998 ini juga diikuti oleh penurunan yang cukup signifikan pada lapangan kerja di sektor manufaktur yaitu sebesar 9 persen. Selain itu inflasi pada tahun 1998 mencapai 77.63 persen yang semula hanya 11.05 persen di 1997. Periode 2007-2008 tampak peningkatan yang signifikan pada impor sektor manufaktur sehingga berdampak negatif pada neraca dan daya saingnya. Pada periode tersebut terjadi pelemahan nilai tukar rupiah terhadap US\$ yang semula Rp 9 419,- /US\$ menjadi Rp. 10 950,- /US\$, sedangkan inflasi naik dari 6.59 menjadi 11.06 persen

Pada periode 2004-2014 pertumbuhan ekonomi Indonesia berkisar antara 5-6 persen sedangkan pertumbuhan manufaktur cukup berfluktuatif dari 2 persen hingga 6 persen. Sebagai penggerak perekonomian, sektor manufaktur tumbuh lebih lambat dibandingkan dengan pertumbuhan ekonomi secara keseluruhan, hal ini mengindikasikan bahwa ada penurunan produktivitas dan perdagangan sektor manufaktur. Jumlah tenaga kerja yang terlibat dalam industri manufaktur, sebagai salah satu input utama dalam proses produksi, cenderung stagnan pada periode 2004-2014. Sedangkan peningkatan modal tetap meningkat hingga dua kali lipat mencapai Rp 688559.8 miliar pada tahun 2014 sesuai dengan Tabel 4.

\section{Dampak keterbukaan perdagangan dan input terhadap nilai tambah manufaktur}

Analisa hubungan keterbukaan perdagangan terhadap kinerja sektor manufaktur dengan model ARDL pendekatan ECM untuk menjawab tujuan penelitian yang kedua. Spesifikasi model yang digunakan didasarkan pada teori faktor produksi. Model persamaan menggunakan variabel nilai tambah manufaktur, modal tetap, jumlah tenaga kerja dan keterbukaan perdagangan yang dapat dijelaskan melalui hubungan jangka pendek dan jangka panjang.

Tahap pertama pengujian data adalah uji stasioner data time series menggunakan Phillip-Perron test dengan tujuan agar memperoleh data yang stasioner. Data penelitian telah diolah dan dinyatakan stasioner (nilai rata-rata dan varian dari data time series tidak mengalami perubahan secara sistemik sepanjang waktu) sesuai dengan tingkat signifikansi pada taraf 5 persen. Variabel yang telah stasioner pada first differences adalah nilai tambah manufaktur (MVA), modal tetal (GFC), jumlah tenaga kerja (Labor), dan keterbukaan perdagangan (TO).

Tahap yang kedua adalah pengujian kointegrasi dengan bound testing approach sesuai dengan penelitian Pesaran et al. (2001),

Tabel 4 Perkembangan ekonomi dan input sektor manufaktur

\begin{tabular}{ccccc}
\hline Tahun & $\begin{array}{c}\text { Pertumbuhan } \\
\text { ekonomi }(\%)\end{array}$ & $\begin{array}{c}\text { Pertumbuhan } \\
\text { manufaktur (\%) }\end{array}$ & $\begin{array}{c}\text { Jumlah tenaga kerja } \\
\text { manufaktur (juta orang })\end{array}$ & $\begin{array}{c}\text { Gross fixed Capital } \\
\text { (miliar Rp, konstan } \\
\text { 2010) }\end{array}$ \\
\hline 2004 & 5.03 & 6.38 & 4.32 & $309,431.1$ \\
2005 & 5.69 & 4.60 & 4.23 & $354,865.7$ \\
2006 & 5.50 & 4.59 & 4.76 & $393,500.5$ \\
2007 & 6.35 & 4.67 & 4.62 & $403,719.2$ \\
2008 & 6.01 & 3.66 & 4.46 & $441,361.5$ \\
2009 & 4.63 & 2.21 & 4.35 & $493,822.3$ \\
2010 & 6.22 & 4.74 & 4.50 & $510,085.9$ \\
2011 & 6.17 & 6.26 & 4.63 & $553,347.7$ \\
2012 & 6.03 & 5.62 & 4.93 & $599,505.5$ \\
2013 & 5.58 & 4.49 & 4.38 & $657,589.1$ \\
2014 & 5.02 & 4.63 & 4.56 & $688,559.8$ \\
\hline
\end{tabular}

Sumber : BPS dan World Bank (2015) 
Tabel 5 Estimasi nilai tambah manufaktur menggunakan ARDL menggunakan pendekatan ECM

\begin{tabular}{|c|c|c|c|c|c|}
\hline Variabel & $\begin{array}{l}\text { Koefisien jangka } \\
\text { pendek }\end{array}$ & Variabel & $\begin{array}{c}\text { Koefisien jangka } \\
\text { panjang }\end{array}$ & \multicolumn{2}{|c|}{$\begin{array}{l}\text { Kriteria pemilihan } \\
\text { model }\end{array}$} \\
\hline CONSTANT & $1.17 \mathrm{E}+13$ & MVA(-1) & -0.029 & $R$-square & 0.972 \\
\hline $\operatorname{DMVA}(-1)$ & $0.601 *$ & $\operatorname{GFC}(-1)$ & $-0.143^{*}$ & $\begin{array}{l}\text { Adjusted } \\
R \text {-square }\end{array}$ & 0.952 \\
\hline $\operatorname{DGFC}(-1)$ & $-0.220 *$ & GFC & $0.182 *$ & $\operatorname{Prob}(F-$ stat $)$ & 0.000 \\
\hline DLABOR & $9018165^{* *}$ & LABOR & $5171807 * *$ & $\begin{array}{l}\text { Durbin-Watson } \\
\text { stat }\end{array}$ & 1.971 \\
\hline DTO & $-4.26 \mathrm{E}+11^{*}$ & $\begin{array}{l}\text { TO } \\
\text { DUMMY }\end{array}$ & $\begin{array}{l}-5.02 \mathrm{E}+11^{*} \\
-8.97 \mathrm{E}+12^{*}\end{array}$ & & \\
\hline
\end{tabular}

Keterangan :

*) signifikan pada taraf nyata 5 persen

**) signifikan pada taraf nyata 10 persen

tujuan uji kointegrasi yaitu ingin mengetahui ada tidaknya hubungan jangka panjang. Uji ini dilakukan dengan Wald-test serta menggunakan uji hipotesis sebagai berikut : $H_{0}=\theta_{1}=\theta_{2}=\theta_{3}=\theta_{4}=\theta_{5}=0 \quad$ (tidak ada hubungan jangka panjang). Penentuan ada tidaknya hubungan jangka panjang dilakukan dengan cara membandingkan nilai F-Statistik yang diperoleh dengan nilai kritis yang telah disusun pada tabel Pesaran dan Shin.

Hasil kointegrasi menunjukan terdapat adanya hubungan jangka panjang antara nilai tambah manufaktur terhadap modal tetap, jumlah tenaga kerja dan keterbukaan. Nilai kointegrasi diperoleh dari nilai F-statistik yaitu 15.54 dan batas kritis 5 persen kemudian dibandingkan dengan hasil yang diperoleh dalam analisis data dimana batas terendah adalah 3.12 dan batas tertinggi adalah 4.25 maka nilai F-statistik yang diperoleh sebelumnya berada diatas batas tertinggi pada tingkat signifikansi 5 persen, yang menunjukan bahwa terdapat hubungan jangka panjang hubungan antara nilai tambah manufaktur dan regressors nya yaitu modal tetap, tenaga kerja dan keterbukaan perdagangan.

Tahapan analisis selanjutnya adalah mengetahui hubungan kausalitas yang terjadi antara variabel dapat diperoleh dengan mengunakan Granger kausalitas. Hasil analisis kausalitas menunjukan bahwa nilai tambah manufaktur mempengaruhi modal tetap dan keterbukaan perdagangan, namun hanya secara satu arah saja. Hubungan dua arah terjadi pada modal tetap dan keterbukaan perdagangan, hal ini mengindikasikan bahwa perdagangan internasional khususnya impor merupakan komponen utama dalam modal tetap dalam manufaktur. Analisis selanjutnya adalah hubungan keterbukaan perdagangan terhadap kinerja sektor manufaktur menggunakan ARDL pendekatan ECM yang dapat dijelaskan pada Tabel 5.

Secara garis besar, berdasarkan analisis jangka pendek, keterbukaan perdagangan secara signifikan berpengaruh negatif terhadap nilai tambah manufaktur. Hal ini mengindikasikan bahwa liberalisasi perdagangan di Indonesia berpengaruh negatif pada produktivitas manufaktur dengan proxy nilai tambah yang semakin defisit. Peningkatan satu persen perubahan keterbukaan perdagangan akan menurunkan (defisit) perubahan nilai tambah manufaktur sebesar 4.26 miliar rupiah, ceteris paribus sesuai dengan penelitian Yanikkaya (2003), Tabi (2011), Hye dan Lau (2012).

Sejalan dengan hasil tersebut variabel modal tetap juga secara signifikan berpengaruh negatif terhadap nilai tambah manufaktur. Peningkatan perubahan modal tetap sebesar satu rupiah akan menurunkan perubahan nilai tambah manufaktur sebesar 0,22 rupiah, ceteris paribus. Secara implisit jika terjadi penambahan modal maka dalam jangka pendek akan mengurangi nilai tambah manufaktur karena modal yang digunakan baru akan dirasakan manfaatnya jika sudah digunakan selama beberapa waktu (akan terasa hasilnya setelah ada jeda/lag yang cukup lama). Penambahan modal tetap meliputi pengadaan, pembuatan, pembelian barang modal baru dari dalam negeri dan barang modal baru maupun bekas dari luar negeri (termasuk perbaikan besar, transfer atau barter barang modal).

Variabel yang secara signifikan berpengaruh positif adalah jumlah tenaga kerja dan nilai tambah manufaktur pada lag 
sebelumnya. Peningkatan perubahan jumlah tenaga kerja sebanyak satu orang akan meningkatkan perubahan nilai tambah sebesar Rp 9.018.165,-,ceteris paribus. Hal ini dapat dijelaskan bahwa mayoritas industri manufaktur yang ada di Indonesia masih merupakan manufaktur padat karya sehingga semakin banyak jumlah tenaga kerja yang dipekerjakan maka semakin bertambah nilai tambah manufakturnya. Sedangkan jika terjadi peningkatan perubahan nilai tambah pada lag sebelumnya sebesar satu rupiah maka akan meningkatkan perubahan nilai tambah saat ini menjadi 0.6 rupiah, ceteris paribus.

Penjabaran analisis jangka panjang menunjukan bahwa keterbukaan perdagangan secara signifikan berpengaruh negatif terhadap nilai tambah manufaktur. Peningkatan satu persen keterbukaan perdagangan akan menurunkan (defisit) perubahan nilai tambah manufaktur sebesar 5.02 miliar rupiah, ceteris paribus. Jika melihat perkembangan neraca perdagangan selama beberapa periode defisit, hal ini terjadi karena nilai impor manufaktur yang lebih tinggi dibanding ekspornya disamping itu komposisi impor yang lebih dari 75 persen merupakan bahan baku penolong untuk industri.

Variabel lain yang secara signifikan berpengaruh negatif pada nilai tambah manufaktur adalah dummy krisis, jika pada tahun tersebut terjadi krisis maka terjadi penurunan perubahan (defisit) nilai tambah manufaktur sebesar 8.9 triliun rupiah, ceteris paribus. Hal ini jelas membuktikan bahwa kinerja perdagangan Indonesia dipengaruhi oleh situasi baik dari dalam maupun internasional seperti Asia Financial Crisis dan depresiasi nilai tukar rupiah. Selain mempengaruhi kinerja manufaktur, krisis juga secara tidak langsung berimplikasi terhadap pembangunan nasional berlawanan dengan penelitian Chansomphou and Ichihashi, (2011).

Selanjutnya variabel modal tetap pada lag sebelumnya secara signifikan berpengaruh negatif pada nilai tambah manufaktur, jika terjadi peningkatan modal tetap pada setahun sebelumnya sebesar satu rupiah akan menurunkan perubahan nilai tambah manufaktur sebesar 0.14 rupiah, ceteris paribus. Kemudian jika terjadi peningkatan variabel nilai tambah pada lag sebelumnya (setahun sebelumnya) sebesar satu rupiah maka akan meningkatkan perubahan nilai tambah saat ini menjadi 0.02 rupiah, ceteris paribus. Sedangkan variabel yang secara signifikan berpengaruh positif adalah jumlah tenaga kerja dan modal tetap. Jika terjadi peningkatan jumlah tenaga kerja sebanyak satu orang akan meningkatkan perubahan nilai tambah sebesar Rp 5171807,-,ceteris paribus. Sejalan dengan hal tersebut jika terjadi peningkatan modal tetap sebesar satu rupiah maka akan meningkatkan perubahan nilai tambah manufaktur sebesar 0.18 rupiah.

\section{Pengaruh faktor guncangan dan random shock terhadap nilai tambah manufaktur, modal tetap dan jumlah tenaga kerja}

Hasil dari Tabel 5 menunjukan bahwa keterbukaan perdagangan secara signifikan dan konsisten berpengaruh negatif pada nilai tambah manufaktur, variabel jumlah tenaga kerja secara signifikan dan konsisten berpengaruh positif terhadap nilai tambah manufaktur. Hasil analisis yang tidak stabil terjadi pada variabel modal tetap dan nilai tambah pada lag sebelumnya. Sedangkan variabel dummy krisis secara signifikan berpengaruh negatif terhadap nilai tambah manufaktur. Setelah mengetahui faktor yang mempengaruhi perubahan nilai tambah manufaktur, selanjutnya akan dilakukan suatu simulasi guncangan faktor dengan analisis impulse response function (IRF).

Hasil analisis IRF menggambarkan dampak saat ini dan masa depan guncangan suatu variabel terhadap variabel endogen (variabel yang digunakan dalam model) yang lain. Respon dalam jangka pendek biasanya cukup signifikan dan cenderung berubah sedangkan respon jangka panjang cenderung konsisten. Dalam penelitian ini, akan dilihat dampak dari guncangan selama 10 periode (10 tahun). Respon guncangan faktor yang mempengaruhi nilai tambah manufaktur dapat dilihat pada Gambar 1. 
Response to Cholesky One S.D. Innovations
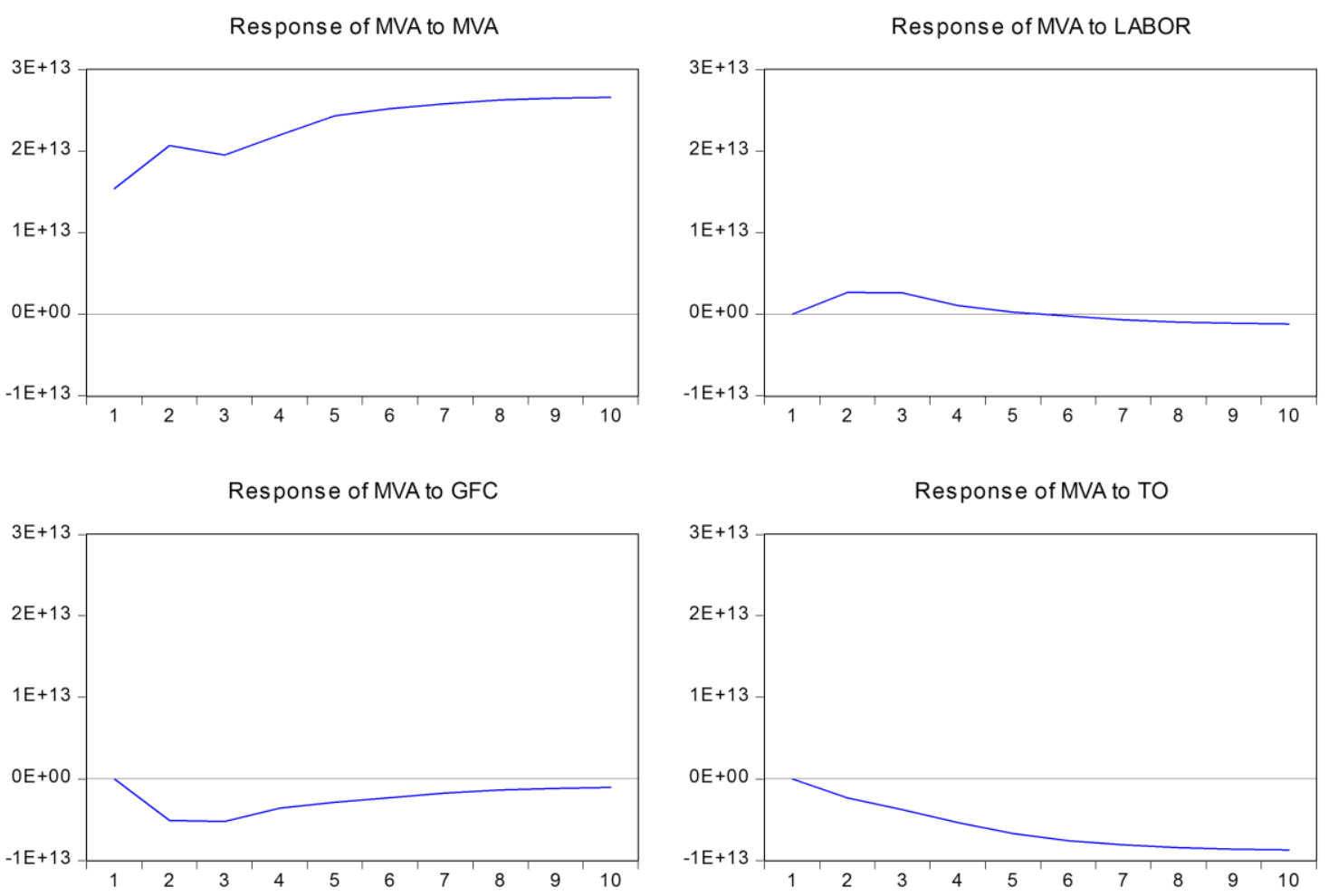

Gambar 1 Respon nilai tambah manufaktur terhadap guncangan nilai tambah, jumlah tenaga kerja, modal dan keterbukaan perdagangan

Periode satu tahun pertama nilai tambah manufaktur menunjukkan respon akibat adanya guncangan nilai tambah manufaktur itu sendiri, jumlah tenaga kerja, modal tetap dan keterbukaan perdagangan. Guncangan dari faktor-faktor yang mempengaruhi nilai tambah manufaktur mulai terlihat pada tahun kedua. Mulai tahun kedua dan selanjutnya, jika terjadi perubahan positif nilai tambah manufaktur akan menyebabkan peningkatan nilai tambah manufaktur dan akan stabil mulai periode kelima.

Guncangan modal tetap bersifat negatif terhadap nilai tambah dan guncangan tersebut stabil pada periode kelima. Hal ini mengindikasikan jika terjadi peningkatan modal tetap yang merupakan faktor input lebih besar dibandingkan jumlah atau kenaikan output maka otomatis nilai tambah akan berkurang. Secara implisit penambahan modal baru akan dirasakan manfaatnya jika sudah digunakan selama beberapa waktu (akan terasa hasilnya setelah ada jeda/lag yang cukup lama). Hal ini dibuktikan dengan kestabilan kurva yang menunjukan perubahan positif mulai periode kelima dan seterusnya menuju kesetimbangan diatas nol.

Guncangan jumlah tenaga kerja manufaktur akan berdampak positif terhadap nilai tambah hanya sampai periode kelima dan akan berdampak negatif pada periode selanjutnya. Hal ini menunjukan dalam jangka pendek peningkatan nilai tambah seiring dangan bertambahnya jumlah tenaga kerja, akan tetapi seiring dengan berjalannya waktu, pekerja akan menuntut upah/gaji serta insentif yang lebih tinggi sehingga pengeluaran input perusahaan pun menjadi semakin besar yang tidak sebanding dengan outputnya. Dampak negatif penambahan jumlah tenaga kerja tampak pada periode ke-enam hingga seterusnya sesuai dengan gambar kurva. 
Guncangan yang tejadi pada keterbukaan perdagangan akan berdampak negatif terhadap nilai tambah manufaktur. Dampak negatif ini dimulai sejak periode pertama hingga seterusnya. Apabila terjadi peningkatan keterbukaan perdagangan maka akan menurunkan nilai tambah manufaktur secara langsung pada periode selanjutnya. Akan tetapi peningkatan keterbukaan ini perlu ditelaah lebih lanjut apakah karena dominasi ekspor ataukah impor. Jika komponen keterbukaan perdagangan didominasi oleh impor maka akan membawa kinerja perdagangan yang defisit baik sektor lain maupun manufaktur. Berdasarkan hasil analisis sebelumnya, struktur perdagangan Indonesia masih didominasi oleh impor bahan baku penolong sehingga dampak negatif keterbukaan tidak dapat terhindarkan. diantara variabel dalam model ARDL dengan pendekatan ECM. Dengan metode ini dapat dilihat kekuatan dan kelemahan dari masing-masing variabel dalam mempengaruhi variabel lainnya dalam kurun waktu yang panjang. Pola dari FEVD mengindikasikan sifat dari kausalitas multivariate diantara variabel-variabel dalam model ARDL. Variabilitas nilai tambah manufaktur secara dominan dipengaruhi oleh nilai tambah itu sendiri sebesar 100 persen. Kemampuan nilai tambah mempengaruhi dirinya sendiri pada periode selanjutnya terus mengalami penurunan hingga pada periode ke-10 sebesar 91.03 persen. Pengaruh jumlah tenaga kerja pada satu periode sebelumnya sebesar 1.01 persen terhadap nilai tambah namun persentase ini berangsur menurun pada periode-periode selanjutnya hingga 0.32

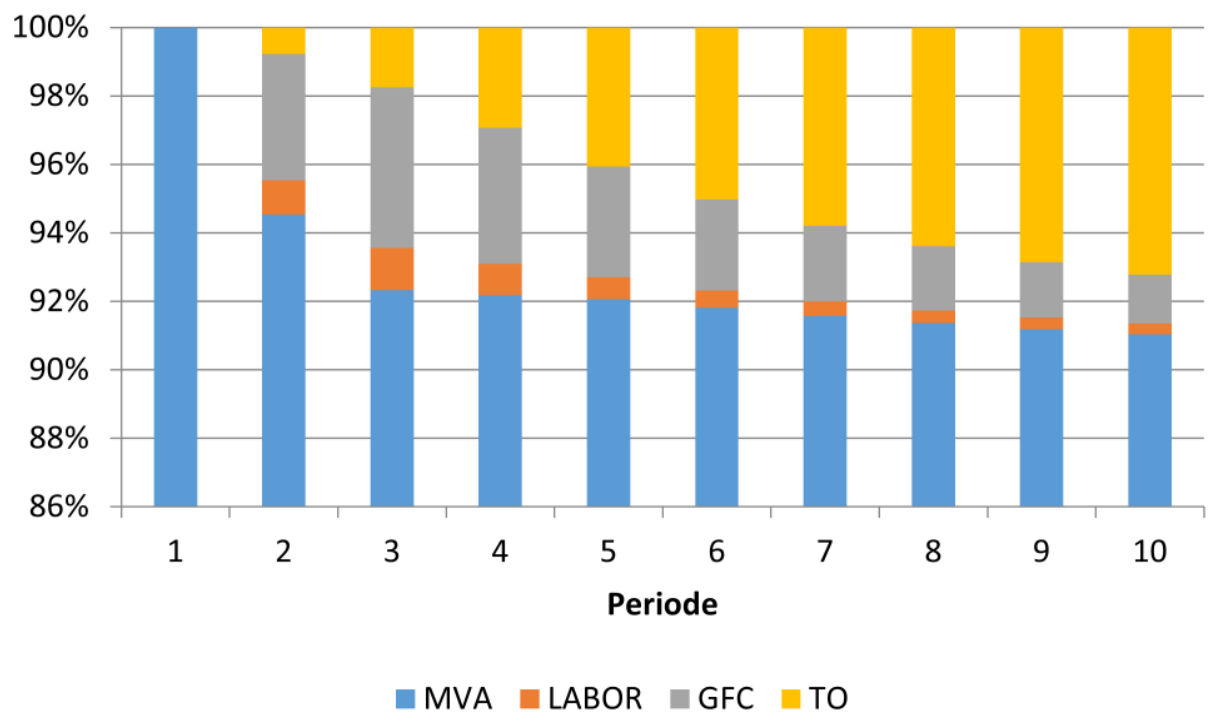

Gambar 2. Hasil FEVD faktor yang mempengaruhi nilai tambah manufaktur

Berdasarkan masing-masing respon tersebut, dapat disimpulkan bahwa respon nilai tambah terhadap impuls yang diberikan oleh nilai tambah itu sendiri bersifat positif dan permanen, sedangkan respon nilai tambah terhadap impuls keterbukaan perdagangan bersifat negatif dan permanen. Sementara respon nilai tambah terhadap impuls jumlah tenaga kerja bersifat positif akan tetapi tidak permanen begitu pula terhadap impuls modal tetap bersifat negatif akan tetapi tidak permanen.

Analisis FEVD digunakan untuk melihat seberapa besar pengaruh random shock persen pada periode 10 .

Begitu juga pengaruh modal tetap pada periode pertama sebesar 0 persen dan mengalami peningkatan sampai 4.70 persen pada periode ke 3 akan tetapi mengalami penurunan hingga 1.43 persen pada periode ke 10. Pada periode pertama, pengaruh keterbukaan perdagangan sebesar 0 persen terhadap nilai tambah. Kemudian pengaruh ini meningkat sampai sebesar 7.22 persen pada periode ke 10. Dengan kata lain, variabel yang berkontribusi besar pada awal periode adalah nilai tambah manufaktur itu sendiri. Setelah periode ke 10 hanya variabel keterbukaan 
perdagangan yang mempunyai pengaruh yang meningkat, artinya dalam jangka panjang keterbukaan lebih berpengaruh terhadap nilai tambah dibanding jumlah tenaga kerja dan modal tetap. Secara implisit besar kecilnya nilai tambah manufaktur tergantung seberapa persen keterbukaan mempengaruhinya.

\section{KESIMPULAN DAN SARAN}

\section{Kesimpulan}

Berdasarkan hasil dan pembahasan penelitian yang dilakukan, maka dapat ditarik kesimpulan sebagai berikut :

1. Secara aggregat, kinerja perdagangan sektor manufaktur Indonesia selama beberapa tahun terakhir mengalami penurunan. Hal ini dibuktikan dengan menurunnya indek daya saing dan keunggulan komparatifnya akan tetapi terdapat beberapa ekspor produk manufaktur yang memiliki keunggulan baik dari perkembangan perdagangan maupun daya saing diantaranya alas kaki, pakaian jadi bukan rajutan, barang-barang rajutan dan kayu, barang dari kayu. Dari segi impor manufaktur terdapat setidaknya lima komoditas terbesar yaitu mesin-mesin/pesawat mekanik, mesin/peralatan listrik, plastik dan barang dari plastik, besi dan baja, dan bahan kimia organik. Produk impor tersebut merupakan barang modal dan bahan baku penolong untuk industri.

2. Keterbukaan perdagangan secara konsisten berpengaruh negatif terhadap nilai tambah manufaktur sedangkan jumlah tenaga kerja secara konsisten berpengaruh positif terhadap nilai tambah manufaktur. Variable modal tetap dan nilai tambah lag sebelumnya berpengaruh dengan tidak stabil dalam jangka panjang maupun pendek kemudian keadaan krisis juga berpengaruh negatif terhadap nilai tambah manufaktur. Respon variabel endogen terhadap guncangan memberikan beberapa respon yang berbeda diantaranya respon nilai tambah terhadap impuls yang diberikan oleh nilai tambah itu sendiri bersifat positif dan permanen, sedangkan respon nilai tambah terhadap impuls keterbukaan perdagangan bersifat negatif dan permanen. Sementara respon nilai tambah terhadap impuls jumlah tenaga kerja bersifat positif akan tetapi tidak permanen begitu pula terhadap impuls modal tetap bersifat negatif akan tetapi tidak permanen

3. Pengaruh dari random shock terhadap variabel endogen menunjukan variabel yang berkontribusi besar pada awal periode adalah nilai tambah manufaktur itu sendiri. Setelah periode ke 10 hanya variabel keterbukaan perdagangan yang mempunyai pengaruh yang meningkat, artinya dalam jangka panjang keterbukaan lebih berpengaruh terhadap nilai tambah dibanding jumlah tenaga kerja dan modal tetap. Secara implisit besar kecilnya nilai tambah manufaktur tergantung seberapa persen keterbukaan perdagangan mempengaruhinya.

\section{Saran}

Adapun saran yang dapat diberikan adalah:

1. Peningkatan daya saing dari sektor manufaktur dapat dilakukan dengan menambahkan jumlah tenaga kerja yang berkualitas meningkatkan produktivitas atau peningkatan modal.

2. Dampak negatif keterbukaan perdagangan terhadap nilai tambah manufaktur terlihat dari nilai neraca perdagangan manufaktur yang defisit, untuk mengurangi nilai defisit dapat dilakukan dengan mendorong ekspor produk manufaktur. Langkah untuk mendorong ekspor manufaktur salah satunya dengan membatasi ekspor bahan mentah atau memberikan kewajiban bagi pengusaha untuk memberi nilai tambah bagi komoditas ekspornya. Selanjutnya untuk meningkatkan ekspor industri manufaktur baik volume maupun nilai yaitu melalui diversifikasi produk ekspor dan diversifikasi negara tujuan ekspor ke pasar non tradisional.

3. Salah satu langkah untuk meningkatkan ekspor manufaktur adalah dengan mengembangkan industri prioritas selain footloose industry.

DAFTAR PUSTAKA 
Balassa, B. 1965. Trade Liberalisation and "Revealed" Comparative Advantage. The Manchester School, 33(2) :99-123.

Balassa, B. 1978. Export and economic growth: Further evidence. Journal of Development Economics, 5(2) :181-189.

Chandran, V.G.R. and Munusamy. 2009. Trade Openness and Manufacturing growth in Malaysia, Journal of Policy Modelling, 31 : 637-649.

Chansomphou, V., Ichihashi, M., 2011. The impact of trade openness on the incomes offour South East Asian countries before and after the Asian financial crisis. Economics Bulletin, 31 :2890-2902

Dasgupta, S and Singh, A. 2006. Manufacturing, Services and Premature Deindustrialization in Developing Countries : A Kaldorian Analysis. Research Paper United Nation University, 2006 (46) : 1-18

Doraisami, A. 1996. Export Growth and Economic Growth: A Reexamination of Some Time Series Evidence of Malaysian Experience. Journal of Developing Areas, 30 (1) : 25-37.

Edwards, L. and Schoer, V. 2001. The Structure and Competitiveness and Industrial Policy Strategy, Annual Forum Muldersdrift.3.

Edwards, S. 1998. Openness, Productivity and Growth: What do we really know?.The Economic Journal, 108 :383-398.

Engle, R. F., and Granger, C. W. J. 1987. Cointegration and Error Correction: Representation, Estimation, Testing. Econometrica, 55 :251-276.

Granger, C.W.J. and R. F. Engle. 1991. Long-Run Economic Relationships, Reading in Cointegration, Advanced Texts in Econometrics. Oxpord University Press, New York.

Harrison, A. 1996. Openness and growth: A time-series, cross-country analysis for developing countries. Journal of Development Economics, 48 :419-447.

Hye, Q.M.A and Lau, W.Y. 2012. Trade Openness and Economic Growth Empirical Evidence from India, Journal of Business Economics and Management, 2015, 16(1): 188-205
Hwang, I. 1998. Long-Run Determinant of Korean Economic Growth: Empirical Evidence from Manufacturing. Applied Economics, 30(3) :391-405.

Jonsson, G., and Subramanian, A. 2001. Dynamic Gains from Trade: Evidence from South Africa. IMF Staff Papers, 48(1) : 197-224.

Mahadevan, R. 2002. A DEA Approach to Understanding The Productivity Growth of Malaysia's Manufacturing Industries. Asia Pacific Journal of Management, 19 :587-600.

Paus, E., Reinhardt, N., \& Robinson, M., 2003. Trade liberalization and productivity growth in Latin American Maunfacturing, 1970-98. Policy Reform, 6(1):1-15.

Pesaran, M. H., Shin, Y., \& Smith, R. J. 2001. Bounds Testing Approach to The Level Relationship. Journal of Applied Econometrics, 16 :289-329.

Rodríguez, F., and Rodrik, D. 2001. Trade Policy and Economic Growth: A skeptics guide to the cross-national evidence. In B. Bernanke, \& K. Rogoff (Eds.). NBER Macroeconomics Annual 2000. 261-325. Cambridge, MA: MIT Press.

Tabi, H. N. 2011. Industrialization of the Manufacturing Sector and Trade Opening in Cameroon. Research in World Economy, 2(1)

Were, M. 2015. Differential Effects of Trade on Economic Growth and Investment : A Cross-Country Empirical Investigation. Journal of African Trade 2 (2015) : 7185

Wong, S. A., 2009. Productivity and Trade Opennesss in Ecuador's Manufacturing Industries. Journal of Business Research, $62: 868-875$

Yanikkaya, H., 2003. Trade openness and economic growth: a cross country empirical investigation. Journal of Development Economics 72, 57-89.

Yousif, K. 1999. On the Role of Exports in the Economic Growth of Malaysia: AMultivariate Analysis. International Economic Journal, 13(3) : 67-75. 